\title{
Том \\ Communicating science: lessons from a Twitterstorm
}

\section{Hannah Little}

Abstract

Keywords

DOI
In early August 2019, the U.S.A. saw 2 significant mass shootings in just 48 hours. On Twitter, Neil deGrasse Tyson responded with a tweet to his millions of followers. He outlined the number of deaths in 48 hours from other causes, and seemed to disparage the human tendency to respond emotionally "more to spectacle than to data". The tweet resulted in an uproar. This "twitterstorm" might provide important lessons for practicing science communicators. The first lesson outlined in this letter is about the use of analogy in science communication, and the second is about how emotion is addressed in science communication.

Public perception of science and technology; Science and media

https://doi.org/10.22323/2.18040101

Submitted: 16th August 2019

Accepted: 29th August 2019

Published: 16th September 2019

In early August 2019, the U.S.A. saw 2 mass shootings, killing at least 31 people in Ohio and Texas, in the space of just 48 hours. On Twitter, people responded with grief, anger, and calls to action on gun laws. However, one science communicator, Neil deGrasse Tyson, responded with an intended learning moment for his millions of followers.

Neil deGrasse Tyson is an astrophysicist and science communicator famous for presenting the television series Cosmos, and being the director of the Hayden Planetarium in New York City. He is famed for his enthusiastic, accessible and humorous science communication content and uses Twitter as a platform to communicate about science. On August 4th, in response to the mass shootings, he tweeted:

"In the past $48 \mathrm{hrs}$, the U.S.A. horrifically lost 34 people to mass shootings.

On average, across any $48 \mathrm{hrs}$, we also lose...

500 to Medical errors

300 to the Flu 
250 to Suicide

200 to Car Accidents

40 to Homicide via Handgun

Often our emotions respond more to spectacle than to data."

The tweet caused an uproar on the platform, in what was a text-book "twitterstorm". The outrage on Twitter led to international news coverage in dozens of news outlets, including The New York Times [Coleman, 2019], U.S.A. Today [Yasharoff, 2019] and The Independent [Zatat, 2019]. On writing, the tweet has reached nearly 82,000 replies, mostly negative. However, some tweeters defended Tyson, countering that it was foolish to take offense at something objectively true, something Tyson nodded to in an apology [Tyson, 2019], stating his regret that his words were "true but unhelpful". Setting aside defenses of objectivity, the outrage that followed might present a couple of lessons for practicing science communicators about the use of analogy and how we respond to emotion.

Lesson 1: use analogy carefully
Tyson's tweet presents an analogy: drawing a comparison between deaths caused by different things. Analogies can be a powerful tool for science communication. However, analogies come in different forms, and we need to think carefully about what type of analogy we're using to explain some situation. Surface analogies use similar objects in the analogy to the objects in the real situation. For example the analogy of Bristol being the San Francisco of the U.K. Both the analogy and the thing being explained are cities. Structural analogies use similar relationships between the objects in the analogy to the objects in the real situation. For example, the analogy of the computer virus infecting software, like a disease would infect a body. In this example, the relationship between the objects is the same ( $x$ infects $y$ ), so it has structural similarity, but not surface similarity (the objects are not similar).

Previous research has found that while using entities that are similar makes analogies more accessible [Holyoak and Koh, 1987], only structural similarity enables accurate learning from analogies [Gentner, Rattermann and Forbus, 1993]. At first glance, it seems that Tyson's tweet uses similar entities (i.e. people, causes of death) and similar structural relations (death caused by $\mathrm{x}$ ), making it appear to be accessible and potentially a good learning moment. However, Tyson's tweet seems to be trying to make a point about the human response to death, and the similarity between the structural relationships between cause of death and human response does not stand up to scrutiny.

Human response to loss of life when there is not a personal connection to the deceased is usually driven by an understanding of human accountability. However, calculating human accountability for death is not very straightforward in most cases, and often requires consideration for many factors, including (but not limited to): human intention, social factors, political factors, environmental factors, and chance. Many of Tyson's examples display human accountability, with some examples being more transparent than others. However, the structural relationship between a cause of death (e.g. flu, murder) and human accountability — and 
therefore human response - is very different for each example. This lack of structural similarity is what leads to an oversimplification of the issues and leads to an analogy that lacks insight and potentially leads to false conclusions.

Lesson 2: don't dismiss emotion
References
The tweet points to an inconsistency between logic and emotion; emotional responses to mass shootings are illogical in light of an absence of emotion for other deaths. It wouldn't be sustainable for humans to start mourning the deaths of everyone, so should we conclude not to mourn at all? Suggesting emotional responses are illogical, especially to something as awful as mass murder, risks shaming people simply for having a very human response.

Furthermore, dismissal of emotion in the name of logic contributes to existing public perceptions that science and scientists are unemotional [Rutjens and Heine, 2016]. This contributes to damaging perceptions that good science cannot exist alongside emotion, and that a lack of emotion creates superiority through better science: an attitude that can be toxic within science, and create barriers for those outside of it. Tyson, as one of the most prominent scientists in the world, with a platform of millions of followers, should be careful not be perpetuate these preconceptions.

Coleman, N. (5th August 2019). 'Neil deGrasse Tyson's Tweet on mass shooting deaths strikes a nerve'. The New York Times. URL: https://www . nytimes . com/20 19/08/05/arts/neil-degrasse-tyson-el-paso.html.

Gentner, D., Rattermann, M. J. and Forbus, K. D. (1993). 'The roles of similarity in transfer: separating retrievability from inferential soundness'. Cognitive Psychology 25 (4), pp. 524-575. https://doi .org/10.1006/cogp.1993.1013.

Holyoak, K. J. and Koh, K. (1987). 'Surface and structural similarity in analogical transfer'. Memory \& Cognition 15 (4), pp. 332-340. https://doi.org/10.3758/bf03197035.

Rutjens, B. T. and Heine, S. J. (2016). 'The immoral landscape? Scientists are associated with violations of morality'. PLOS ONE 11 (4), e0152798. https://doi.org/10.1371/journal.pone.0152798.

Tyson, N. D. (5th August 2019). Twitterstorm. Facebook note. URL: https: //www . fac ebook.com/notes/neil-degrasse-tyson/tweetstorm/10157492889446613/.

Yasharoff, H. (5th August 2019). 'Neil deGrasse Tyson apologizes for tweet about mass shootings: 'I got this one wrong"'. U.S.A. Today. URL: https://eu . usatoda y.com/story/entertainment/celebrities/2019/08/04/neil-degrasse-tyson -slammed-tweet-el-paso-dayton-shootings/1916347001/.

Zatat, N. (5th August 2019). 'Neil deGrasse Tyson draws criticism for response to America's mass shootings'. Indy100 from the Independent. URL: https : / /ww . indy100.com/article/el-paso-shooting-neil-degrassetyson-response-twitter-9039721. 
Hannah Little is a Senior Lecturer in Science Communication at UWE Bristol. She has a background in cognitive science and linguistics. Her research interests are digital communication, public speaking, linguistic and cultural evolution, experimental methods and data analysis. She is also a keen communicator of science and technology, especially on subjects around language, evolution, and data rights. E-mail: hannah.little@uwe.ac.uk.

Little, H. (2019). 'Communicating science: lessons from a Twitterstorm'. JCOM 18 (04), L01. https:/ / doi.org/10.22323/2.18040101. 